\title{
Wildland-Urban Interface fires in Spain: summary of the policy framework and recommendations for improvement
}

\begin{abstract}
Southern Europe is recurrently being hit by forest fires affecting wildland-urban interface (WUI) areas which, particularly in the last decade, have resulted in tremendous consequences. In the years to come, self-protection of communities will be a first priority over fire suppression, demanding better fire-resistant and resilient WUI scenarios through actions grounded on solid and sound regulations and legislation. As of today, the European Union as a whole, and the Member States in particular, are belatedly articulating new and appropriate regulations and implementing policies for the protection of WUI areas against forest fires. Spain is one of the EU Member States, holding 1.1 million ha of WUI areas (above 4\% of the total forested land) and experiencing an average of 12,500 forest fires per year over the past decade. In this paper a review of the state of the art on regulations, codes, plans and recommendations on WUI fire prevention and management in Spain is presented. Shortcomings due to the current lack of building and urban planning standards and technical codes for WUI communities are highlighted. We underline some paramount needs to be covered by scientific research and fire engineering in particular topics. Some of them have received little attention in the literature related to European WUI fires while some others have been almost unexplored, such as planning of low-fuel fringes, design of road networks and accessibility, dimension of water supply networks, study of ignitability and combustibility of residential vegetation, role of construction methods and materials, and the wildland-industrial interface. Outcomes from research activities on such topics should lead to appropriately drive and inform the policy making processes on WUI fire prevention and management in Spain and, by extension, in other Southern European countries under a similar situation.
\end{abstract}

Keywords: wildfire, community infrastructure, fuel treatments, wildland-industrial interface, WUI standards. 


\section{Introduction}

Forest fires affecting urban and rural communities, the so called wildland-urban interface (WUI) fires, represent a rising problem in Europe. As the climate steadily evolves towards warmer scenarios, hot and dry seasons in southern countries are lengthening and wildfires are showing extreme behaviour with huge intensities and enormous destructive potential [1]. Climate change is also causing the WUI in northern countries to be progressively located in emergent fire-prone zones [2], whose policies and communities today are not adapted nor designed to deal with large and destructive wildfires. In addition, human pressure in European natural areas is continuously growing with an increase of ignitions and man-built structures in the WUI [3]. The affected constructions include not only homes and other community structures but also industrial facilities, which may eventually involve technological and economic risks associated to the presence of hazardous materials (e.g. chemical and petrochemical industries, oil and gas facilities, nuclear plants, etc.) and the potential loss of revenue [4].

Recently, forest fires affecting WUI areas have lead to tremendous consequences in Europe. In 2016, wildfires blazed Madeira Island spreading through the old quarter of the capital Funchal; almost 2000 people were evacuated in two WUI fires in Valencia with fire jeopardizing dozens of touristic developments; the Rognac-Vitrolles fire devastated 300 ha at the interface with Marseille, one of the most crowded cities in France. In this incident, the fire also threatened critical infrastructure (i.e a petrochemical complex, a water treatment plant and the Marignane International airport). In 2017, Portugal experienced the deadliest WUI fires in its history, with more than 110 deaths, and thousands of affected structures, including industrial facilities. And more recently (July 2018), fires in Greece killed around 100 people, trapped and burned inside their houses, cars or a few meters away from the beach. Overall consequences of current fire season in Europe are still unknown, but as for 2017, the global wildfire impact involves 1.2 million ha burnt, 127 people killed and 10 billion $€$ of economic losses [5].

These hard facts reveal that the design and implementation of a common strategy for the defence and prevention of forest fires in Europe is utterly needed. In the meantime, the European Union as a whole, and the Member States in particular, are belatedly articulating new and appropriate regulations and implementing policies for the protection of WUI areas against forest fires. Indeed, there is a clear will of achieving some degree of coordination through the EU member states in forest fires-WUI fires related protocols and regulations. As illustrating examples, up to now particular EU harmonized tools and systems can be mentioned as a result of EU legislation like the Copernicus Emergency Management Service (which provides reliable information on fire 
danger and fire monitoring at European level) or the Civil Protection Mechanism supported by the Emergency Response Coordination Centre (ERCC, created to ensure a rapid and effective assistance in disasters). However, although fairly recommended [6], a whole harmonized system through EU is far from being a reality due to several critical issues. To begin with, the definition of WUI and WUI fire related terms is still vague and not common to all the countries [7]. In addition, current WUI national safety management policies are highly intricate involving a complicated multi-level structure (i.e. from national to municipality level), with provisions differing significantly between countries, and with an overall low degree of compliance.

There is hence a clear need to address the WUI fire policy analysis and improvement at national level as European mechanisms are not harmonized and standardized. Yet, it is focussing on local realities (in terms of landscape, ecosystems, meteorological conditions, socio-economic systems, land use, etc.) that solutions for the WUI fire global problem have to be found. These necessarily involves improving the knowledge base on WUI fire behaviour and risk at local scale, which will then be channelled into scientific-based recommendations for policy improvement.

In this paper a review of the state of the art on regulations, codes, plans and recommendations on WUI fire prevention and management in Spain is presented. Shortcomings due to the current lack of building and urban planning standards and technical codes for the fire protection of buildings and communities in the WUI are highlighted. We underline some paramount needs to be covered by scientific research and fire engineering in some specific topics, namely fuel-reduced fringes, access roads, water networks, residential vegetation, construction practices and materials, and the wildland-industrial interface. In general, these areas have been insufficiently explored in literature related to European WUI fires while some are almost inexistent (e.g. wildland-industrial interface). The present paper stresses the importance of future developments in research so to appropriately informing and driving the policy making processes on the WUI matter in Spain and, by extension, in other Southern European countries under a similar situation.

\section{WUI fire management in Spain}

\subsection{Overview of the problem}

Spain, like any Mediterranean country, experiences frequent forest fires every year. The exposure to fire of human-built structures is high, particularly along the eastern coastline and in the northwest, where 1.1 million hectares of land are classified as WUI [8]. Moreover, part of this interface is usually highly populated during the fire season, as Spain is a favoured tourist destination in summer. Fig. 1 depicts the normalized contribution of each autonomous region to 
the total area burned in Spain due to wildfires. Autonomous regions located in the northwest of the Iberian Peninsula are the ones that most contribute to wildfires, whereas those located in the northeast are the ones with the lowest contribution.

Fig. 1 Contribution of autonomous regions to the total area burned in Spain due to wildfires. The color code shows red regions with the highest contribution; orange-yellow regions with medium contribution; green regions which contribute less to total burned area. Source: [9]. Values for each region are obtained by computing the ratio between the burned area of an autonomous region over its total forested land (mean value between 2001-2010), and the area burnt in Spain over all Spanish forested land (mean value between 2001-2010). Normalization is obtained by dividing each value by the maximum ratio of the dataset.

There are several types of WUI identified in Spain defined according to housing and vegetation density and type [10]. The ones with higher risk are (Fig. 2) i) scattered houses in developed areas, without any type of landscape planning, some of them in illegal or in lawless condition. This type of WUI hardly has common infrastructure and administrative organization; ii) isolated houses in wildlands where forest exploitation has progressively been abandoned. In these cases, flames can reach structures very easily; iii) dense housing with a rambling road network, with residential fuel continuity, typical from the Mediterranean coast touristic developments.

Fig. 2 Types of WUI: a) Isolated houses in a scattered residential area; b) Isolated (burnt) house in rural area in Monchique (Portugal); c) Dense housing in Mallorca Island (Balearic Islands) touristic development.

Constructive components, methods and practices used in Spain are those frequently found in Mediterranean buildings. Bricks and concrete are the materials commonly used to erect walls and structure, and clay tiles for the roofing, so the vulnerability is significantly lower when compared to areas where wood or other combustible materials are primarily used. Openings in the buildings are the major weak points of houses when facing a forest fire. Forensic analyses of burned dwellings show that some points in the building such as vents, windows and doors left opened in the evacuation process, allowed the entrance of firebrands and hot gases compromising the whole structure $[11]$.

Opposite of what is observed in other countries (i.e. USA), houses affected by wildfires in Spain (and by extension in southern Europe) may stand erect, and even recoverable and reusable to some extent, after the fire event. In this sense, five levels of impact may be considered, according 
to the observed damage and likelihood of re-usage afterwards, namely: (i) No damage. There is no appreciable effect on the exterior elements, structure and interior are unaltered; (ii) Light damage. Some non-structural elements are affected, mostly external components frequently made of plastic. Some annexed service buildings may be affected; (iii) Moderate damage. A section of the house has been partially burned down, such as a room or part of the roof, some windowing and maybe annexed buildings are also affected. The structure is unaltered and fully reusable without major recovering works; (iv) Severe damage. The roof probably has collapsed entirely, most of the rooms are burned down and there are evidences of complete internal burning and fire propagation. Major reconstruction is required, but the main structure of the house is still safe to be reused. Major works need to be undertaken. Recovery of the house is frequently a matter of balancing the associated costs of recovery vs. demolition and rebuilding; $v$ ) Complete destruction. The structure is irrecoverable as it presents significant cracks, displacements and other evidences of serious damages. Demolition is advised.

It is interesting to underline that this fact also provides opportunity for the post-fire investigation and the gathering of evidences, so to derive valuable lessons, as wooden houses frequently burn down to ashes giving very few evidences. According to the experience in past fires, the level (iv) is frequently perceived by owners and authorities as 'totally destroyed' while it is still recoverable. This type of classification should be adopted by insurance companies, but also to be used in the studies and mapping of house affections so to consistently derive lessons learnt.

Apart from interfacing wildland fuels (forests, shrublands or grasslands), WUI communities include also residential fuels (natural or non-natural), present in the exterior of the house in the garden, under porches, piled in the backyard, etc. whose hazard is in general poorly characterized and frequently disregarded by residents. These fuels are exposed to firebrands either generated by a wildfire or by burning structures. They can also be ignited by flame contact from the main fire front in cases where wild fuels are too close to communities. Ornamental trees or hedges, wood piles, pruning waste, wild fuel in undeveloped lots, fences, hydrocarbon storage bottles and tanks, gas canisters, garden furniture, outbuildings (e.g. storage sheds, pet houses, gazebos), etc. usually create fuel continuity through which the fire can easily percolate and may involve high heat loads in case of ignition. Furthermore, industrial interface is also present in Spain, particularly in the most active regions (e.g. Catalonia) where facilities as well as critical infrastructure (e.g. power lines, transmission lines, etc.) meet with or are dispersed within wildland vegetation.

As in all WUI fire-prone areas, WUI fires in Spain pose enormous management challenges in terms of civil protection and fire mitigation. These fires often exceed the capacities of firefighters, who have to respond simultaneously to wildfire suppression, community evacuation and 
structures protection. The presence of smoke and firebrands, as in other parts of the world, complicates scenarios and frequently entails dilemma whether to evacuate or shelter in place. In fact, legal obligation to primarily defend people and properties, causes an unbalanced amount of firefighting resources into the urban area at the expense of the wildfire. In addition, some Spanish regional fire services (i.e. Andalucía, Extremadura, Castilla León) are clearly split in two differentiated divisions (wildfire-fighters and urban fire-fighters) being none of them completely prepared (in terms of equipment and training) for interventions in WUI scenarios.

The forecasted trend for Spain in the coming years involves the concurrence of: $i$ ) an increase of WUI-fire prone areas due to the continued urban sprawl interfacing wildlands; $i$ ) the upsurge of new fire regimes due to climate change leading to more frequent and intense fires; and iii) an increase of fuel accumulation contributing to the fire power, due to sustained rural abandonment and lack of efficient fuel management programs [12-14].

\subsection{Legal framework}

In Spain, as in all member states of the EU, the subsidiarity principle applies, i.e. the local administrations are key actors co-responsible of forest fire prevention and defence in WUI areas. As such, national laws are transferred to the 17 autonomous regions which, in turn, have to articulate those laws issuing local regulation and guidelines, and ensuring compliance of provisions at municipal level (Fig. 3).

Fig. 3 WUI regulatory framework in Spain. Adapted from [15] with permission

The general regulation which applies to WUI fire prevention and mitigation emanates from three basic domains: Forestry, Civil Protection and Building. Among other aspects, the Forestry Act [16] recognizes competency of autonomous regions to rule on forest fire prevention and mitigation, including safety regulations on activities, buildings and infrastructure that could entail a certain forest fire risk or be vulnerable in case of any forest fire incident. In particular, the Forestry Act explicitly establishes the obligation of regions to regulate on prevention and protection against fire in WUI areas. Policies have to be done according to the provisions established in the Basic Guideline on Civil Protection for forest fire emergency [17] by which the Civil Protection Act [18] is developed. Furthermore, the Forestry Act points out the requirement for the autonomic regions to determine high wildfire risk areas (HWRA) which can include WUI. 
In turn, the Basic Guideline on Civil Protection establishes general guidelines for preventive measures to be adapted and articulated by each of the autonomous regions in terms of fuel management and defence infrastructure in the vicinity and inside WUI areas (mandatory for HWRA and recommended for lower risk areas). Specifically, three main provisions are considered: firstly, a 30-m (or 8 times the vegetation height) width fuel reduced strip has to be performed around WUI areas, with cleared arboreal strata and free of dead vegetation. Secondly, roads in high wildfire risk areas have to be $3 \mathrm{~m}$ (one-lane road) or $5 \mathrm{~m}$ (2-lanes road) wide, with a 5-m minimum internal turning radius and with a $5 \mathrm{~m}$ height free of obstacles. Slopes cannot be higher than $12 \%$ (exceptionally $20 \%$ ) and there must be a zone for changing direction every 200 $\mathrm{m}^{2}$. Finally, WUI areas must have a hydrant network with $100 \mathrm{~mm}$ diameter pipelines ensuring 1 bar of pressure at the outlet, and $171 \cdot \mathrm{s}^{-1}$ of minimum flow rate.

These are the minimum provisions that have to be transcribed into regional planning and policies, which in turn have to be deployed through Prevention Plans at local (i.e. municipality) level. The degree of development of regional regulations and guidelines varies from one autonomous region to another. In Table 1, a summary of provisions applied in autonomous regions with a higher degree of planning deployment is presented. It is worth noting the differences between the 17 Spanish autonomous regions in terms of fuel treatments, access roads and hydrants at the WUI, both regarding the degree of development and the particular fine details addressed in the provisions.

Apart from these aspects, it has to be highlighted that Prevention Plans at local level (municipality) have to consider societal risk awareness, education programs and surveillance actions. Furthermore, self-protection for home owners or any type of building holders at the WUI has to be also contemplated. Prevention plans have to program the development of actions to inform and promote best fire prevention practices for the owner. On the other side, WUI buildings (or groups of buildings) must have their own self-protection plan, including basic preventive measures and actions to ensure personal safety and to minimize consequences in assets due to fire effects. In turn, self-protection plans are part of the local emergency planning by which all actions and procedures related to the emergency management are established (e.g. evacuationconfinement protocols, resources and roles of the organizations, etc.).

Finally, the last pillar that has to be considered in terms of the legal framework applied to WUI is the building regulation. The Building Code [19] adds some more constraints in terms of firebreaks configuration and access roads in WUI areas. The main provisions are: $i$ ) perimetric fuel-reduced strips of land protecting communities must accommodate a $5 \mathrm{~m}$ wide road; ii) at least two access points must be included in the street network in WUI communities or, alternatively, one access road ending at a circular (12.5 m radius) cul-de-sac. Nevertheless, no provision in the Building 
Code is specifically devoted to set measures to improve construction and thus better equip buildings to withstand the effects of wildfires.

\section{Wildland-industrial interface regulatory framework}

Fire safety in Spanish industrial facilities is designed and implemented following particular regulations according to the specificity of activities (e.g. nuclear, chemical, oil and gas, etc.). However, a general framework is delineated by a national regulation [20] in which appropriate provisions for industries at the WUI are included. Those provisions basically involve the two ones previously listed from the Building Code. In addition, a particular refinement regarding the fuelreduced strip is added in locations where strong winds are frequent. For locations with these eventual conditions, the fringe width should be at least $50 \mathrm{~m}$.

Particular national regulation also applies to domestic gas supply facilities (mainly liquefied petroleum gas -LPG- storage tanks) present at the WUI, which represent another specific situation where industrial type risk merges with wildfire risk. Spanish standard UNE 60250 [21], the reference regulation dealing with this type of risks, specifies, among others, safety distances from the LPG supply unit to vulnerable elements, operation conditions, fire extinguishing systems and other protection measures that have to be taken into account. In particular, this standard indicates that for 1 to $5-\mathrm{m}^{3}$ tanks, safety distances should be of $2 \mathrm{~m}$ from the walls of the tank and $3 \mathrm{~m}$ from the service orifices. These distances can be reduced by a $50 \%$ for smaller tanks. The standard also states that the LPG unit should be provided with an enclosure made of metal mesh or other materials with very limited contribution to fire, to avoid manipulation from non-qualified personnel. Nevertheless, this measure can be ignored if the tank is located inside a single-family house plot with perimeter elements delimiting the property and preventing the access to outsiders. However the above, the standard makes no explicit mention to natural fuels (e.g. nearby forest or ornamental vegetation in the garden), usually present at the WUI microscale, which can be located inside the plot and be eventually ignited in case of WUI fire.

Although Spain has a rather well developed legal framework, the degree of compliance is generally poor. Greenpeace Spain has recently conducted a survey [15] on fire prevention and emergency planning deployment in the different autonomous regions of Spain. The study has revealed that the autonomous regions of Asturias, Galicia, Cantabria and Euskadi, and the provinces of León and Zamora (in Castilla León) have the 52\% of the fires in Spain, but their fire management plans are deficient or very deficient. In particular, Greenpeace Spain states that $80 \%$ of Spanish municipalities located in HWRA do not have local Emergency Plans. On the side, the survey also highlights the autonomous regions of Catalunya, Extremadura and Andalucía as the ones with a better degree of planning implementation. 


\section{Discussion and assessment of fire engineering research needs}

Wildfires are recurrently harming people and damaging properties in Spain. Far from improving, the problem is expected to worsen in the coming years mainly due to climate change and the lack of policy compliance and adaptation to the new WUI fire scenarios (either the presence of WUI in new fire-prone zones or the unprecedented extreme fire behaviours affecting WUI areas). Spain possesses a complex legal framework that requires a delicate coordination between administrations, not only at different levels (e.g. national and regional; regional and local) but at the same stage among regions and among municipalities. It is on these later on which the responsibility of fire protection to population and assets falls. At this local level, policy implementation is highly defective and with significant differences between regions and provinces, due to the lack of risk culture and awareness in some municipalities or to limited economic and technical resources in some others [15]. However, even in the regions with more matured and developed planning and implementation of prevention measures, there are no reliable evidences that safety provisions will deliver the required degree of protection for the next generation of WUI fires. Indeed, regulations are mainly general rules based on experience, but frequently poorly supported by scientific evidence and studies, thus without taking into account the appropriate parameters and processes that explain fire behaviour and effects on assets at the relevant scale (i.e. home-owner scale). Moreover, there are still significant gaps on important aspects that have to be addressed, and at some degree regulated, to increase the resistance and resilience of WUI communities against fires, whether they are residential fuel reduction or building practices and materials, to give some relevant examples.

The research needs discussed below respond to the requirement of policies developing provisions and recommendations based on scientific knowledge. These research questions particularly arise from the need to better define and characterize: (1) fuel-reduced strips according to significant fire behaviour and exposure parameters; (2) water networks and (3) road networks for efficient fire-fighting and emergency management; (4) the role of residential vegetation on fire percolation and impact; (5) more fire-resistant construction practices; and (6) industrial and wildfire risk interaction.

\section{Fuel-reduced fringes}

Spanish National Acts give a general fixed value of $30 \mathrm{~m}$ for fuel-reduced fringes width around WUI communities, despite the specificity of local fire behaviour parameters (i.e. weather, terrain, fuels) or fire exposure conditions on structures. This quantity is consistent with the US widely applied Home Ignition Zone (HIZ) concept [22], in which a safe distance of $30 \mathrm{~m}$ is recommended from homes to the wildland for flat to gentle slopes. It is important to note that HIZ was 
established according to the results obtained in experimental crown fires $[22,23]$ in which the potential of wood structures ignition through flame radiation was investigated under a limited set of environmental conditions (flat ground and no wind). Although empirically-based, a 30-m safety distance has been required as a baseline safety measure for all WUI fire communities in Spain without any type of refinement, and hence considered inefficient in some regions. As such, further development has been transcribed into regional regulations or recommendations in Galicia, Principado de Asturias, Catalunya, Extremadura and Comunitat Valenciana, where simple rule-based methods (resulting from observation and expert opinion) have been set in order to consider meteorological conditions, slope or fuels for fuel-reduced fringe width sizing (see Table 1). None of them, however, have been developed according to a physics-based approach, taking into account any equation (in some approximation) of heat transfer processes. There are illustrative standards in the literature to size up safety zones following simplified but systematic approaches that account for the level of radiant heat exposure in the WUI. As an example, the Australian Standard AS 3959-2009 [24] is based on state-of-the-art analytical expressions for flame physical characteristics and relies on the solid flame model [25] for radiative heat transfer to quantify the level of wildfire threat which in turn is used for defining particular fire prevention measures. This standard can inspire similar approaches to be adopted in Spain and elsewhere, provided flame geometry is adequately defined according to weather conditions and specific fuel types and strata. Apart from radiation, it has been acknowledged that other modes of heat transfer (i.e. firebrands and convective heat in wind-driven fires and through flame contact) play also a key role igniting structures [26]. For this reason, any scientific-based approach developed to protect WUI communities should include complementary strategies to consider this complex phenomenology.

Regarding fuel treatments within the fringe, National Acts are nonspecific, only mentioning the need for dry vegetation removal and canopy clearance. Seven out of 17 autonomous regions have defined rules of thumb based on educated criteria for canopy cover or treetop distances (see Table 1). Although they represent quantitative measurements that can be easily implemented in the field, they are mostly arbitrary, significantly differing from one region to another, and their efficiency has no scientific evidence. Fuel treatments modify fire behaviour, but the resulting change from specific treatments has not yet been fully investigated by the scientific community [26]. Testing methodologies to characterize wildland fuel treatments adjacent to communities (either empirically-based through prescribed fire scenarios or post-fire investigations, or physicallybased methods by using computational codes) have to be hence defined and implemented for appropriate benchmarking of fuel treatment efficiency. 
Access roads

Access road characteristics are regulated by Spanish National laws based on the need of firefighter vehicles safe transit. In particular, provisions are established for minimum widths, turning radius, slopes and passing and turning places for entry ways in WUI communities. Although adequate road sizing is needed to guarantee the safe mobility of tracks, it is obviously limited by current land-use, hence being some of the provisions hard to fulfil in already existing WUI developments. There is no explicit mention of fuel treatments in access roads by National Acts, being this subject therefore considered at regional level. Some autonomous regions have issued provisions or recommendations regarding fuel conditions interfacing roads with the aim of enlarging distances from burning fuels to vehicles and hence reducing heat exposure (see complementary provisions for Catalunya, Comunidad de Madrid, Extremadura and Comunitat Valenciana in Table 1). Again, these provisions are not exempted from arbitrariness and lack of scientific-based efficiency assessment.

Regarding WUI roads, facts in recent forest fires show that roads are the places of frequent fatal entrapments. Fire incident analysis has revealed a high number of casualties corresponding to people caught on the road while escaping from the fire. In Portugal (2017) 58 people died in or near their cars when the fire overtook several rural roads. During the devastating wildfires in Attica, Greece (July, 2018), several dozens of vehicles were trapped by flames, firebrands and smoke when fleeing from the fire heading towards the coastline, as a consequence of which the dead toll raised remarkably. According to current legislation, roads must be designed to be safe for fire-fighting tracks, but these recent WUI fire incidents reveal that current road systems are being completely overlooked by fire managers and decision-makers as evacuation networks for civilians. Fire evacuation modelling has been a hot topic within the fire engineering community [27], but it has been mainly addressed to fires in buildings and with limited coupling between fire and smoke models, pedestrian models and traffic models. Although a comprehensive tool to help decision making processes in case of WUI fire evacuation is not yet available, some recent research efforts are already pointing to the development of an integrated simulation system for WUI fire evacuation expected to aide emergency planning and management [27].

\section{Water network}

The provisions regarding water use during WUI fires in Spanish National Acts are aimed to guarantee a minimum water flow rate and pressure through the hydrant network around WUI communities. In some autonomous regions complementary requirements are set in order to ensure a simultaneous use of hydrants in the perimeter (particularly two hydrants must be normally operating at the same time during two hours with the necessary flow rate and pressure in 
Comunitat Valenciana and Catalunya). Due to spotting activity (either coming from the main wildfire or from structures or residential fuels burning), WUI fires are commonly characterized by a simultaneity of scattered plots affected by fire both at the perimeter and at the interior of communities. Current provisions are thus insufficient to cope with the high degree of fire attack dispersion that this situation involves.

This is an aspect where further progress should be expected, yet with available mathematical programming schemes for water networks design proved useful (e.g. [28]). Advanced optimization algorithms can inform engineers and decision-makers for optimum design of water networks according to pipe and tanks sizing and siting, operational costs and the required firefighting capacity.

On the other hand, it is interesting to note that some alternative private infrastructures, both at the community and the home-owner scales, are becoming more and more accepted and used in Spain as a valid self-protection measure, and as a complement to the resources provided by the public water networks. These solutions, still in the preliminary stages of research, point however an interesting and suitable rationalisation of water consumption, while effectively accompanying fire fighting operations in the WUI [29].

\section{Residential vegetation}

Spanish WUI communities are typically characterized by the presence of all types of residential fuels, both natural and non-natural, that may help flame progression through the community in case of fire. More in particular, residential vegetation can play a crucial role helping in the percolation of the fire through plots and between structures, lit either by spotting, radiant heat exposure or direct flame contact (Fig. 4).

Fig. 4 a) Fire percolating through cypress hedgerow limiting a plot at the WUI (Source: Bombers Generalitat de Catalunya); b) Burnt scars of a WUI fire in Benitatxell (Comunitat Valenciana, 2016) with noticeable fire percolation through residential fuels

Although national laws do not look into such a detailed scope, several autonomous regions have already issued some recommendations to improve self-protection and foster societal awareness regarding: $i$ ) flammable species to be avoided in gardens; ii) distances between ornamental trees or between façades and vegetation; and iii) combustible materials to be avoided as fences. Moreover, particular regions (e.g. Catalunya, Comunitat Valenciana and Comunidad de Madrid) 
have complementary requirements regarding mitigation of forest fuels in undeveloped plots (see Table 1). These plots have to be also managed similarly as it is done for fuel-reduced fringes, so to minimize plot-to-plot fire progression, further firebrand generation and scattered fire outbreaks due to spotting.

While these efforts are acknowledged, existing guidelines need to be improved, expanded and supported by scientifically-based findings that might or might not be in line with empirical observations and current field insights. Knowledge base on residential fuels fire hazards has to be hence enlarged for better fuel management strategies and precisely informed standards. There is evidence of the most commonly involved and hazardous residential fuels in WUI incidents. However, little is known about ignition probability (either through firebrands, fire radiation or direct flame contact), energy released, flame dimensions, fire residence time and best treatment practices related to these types of fuels (e.g. thinning, pruning, watering, etc.) to minimize fire effects when ignited. In particular, serious difficulties are found to mimic in the laboratory the fuel distribution and combustion of some vegetal structures heavily treated and transformed (such as green hedges) which, after several years accumulate large quantities of dead material inside. This quantitative information on real-scale fire hazard is decisive for adequate risk assessment and management at home-owner scale and for community awareness. Experimental programs at real scale to characterize combustibility of residential fuels are clearly needed, particularly regarding ornamental vegetation, whose flammability has been so far studied only at analytical scale (e.g. [30-32]). In this context, it has to be highlighted a recently started novel research effort lead by CERTEC (Universitat Politècnica de Catalunya - BarcelonaTech) and funded by the European civil protection agency aimed at providing scientific answers to residential fuel hazard management focused on both real-scale experiments and computational modelling research [33].

\section{Construction practices and materials exposure}

Construction practices and building materials are responsible, together with residential fuels, of vulnerabilities in WUI communities at home-owner scale. Although building materials commonly used in Mediterranean countries are non-combustible, houses at the WUI always have weak elements to fire exposure (e.g. glazing and flooring systems, decks and verandas or eaves and gutters). This type of elements are responsible of vulnerabilities, either because they are made of materials sensitive to fire or either because their geometry enhances heat transfer. For example, ignition likelihood from embers might increase by re-radiation mechanisms in re-entrant corners $[34,35]$. Local turbulence and flame entrainment from residential fuels might be induced in angled and edgy façades, and semi-confined spaces [36]. Among them, some elements composing 
the building envelope, like vents, doors or windows, are particularly critical since they may allow the entrance of firebrands leading to ignition of the interior of the building.

The Spanish Building Code, however, does not add any particular provision in terms of characteristics, materials and dimensions in the design and construction of houses at the WUI. Although some autonomous regions (e.g. Extremadura, Comunitat Valenciana) have issued recommended guidelines for refurbishing and passive protection, and have prepared check-lists to help home-owners increase self-protection, the degree of detail is scarce and none of them have really enforced any instruction not even referred to minimum standards.

There is hence a clear need of a certain degree of regulation regarding where and how buildings can be sited, designed and constructed to increase chances of building survival when exposed to incoming fire regimes. Moreover, countries in southern Europe and Spain in particular, have to take advantage of historical fire-resistant building materials to help reinforcing overall fire endurance of Mediterranean style homes in order to increase their sheltering capacity. Standards have to be developed to assess capabilities and adequacy of buildings acting as shelters. Spaces for programmed shelter in place could enormously benefit emergency management, minimizing the number of evacuations and facilitating overall fire-fighting actions.

\section{Wildland-industrial interface}

Forest fires can trigger industrial accidents giving rise to a natural-technological (Natech) emergency which may pose tremendous fire management difficulties regarding fire suppression and civil protection. This particular type of domino effect is considered an emerging risk in Europe due to new fire regimes and growing industrialization [37]. Management of Natech type of risks has been generally addressed through national legal frameworks for industrial accident prevention in Europe. However, Spanish legislation does not have any particular regulatory support different from the general WUI provisions (excepting an increase of the fringe width in windy areas) in wildland-industrial interface zones. The European Commission has already recognized the scarcity in guidance for Natech risk reduction supporting policy makers, being the lack of specific Natech risk-assessment methodologies and tools a priority research need [37].

Smaller scale Natech scenarios have also been identified at home-owner level in WUI communities, mainly involving domestic LPG storage tanks and nearby vegetation [38]. Hydrocarbon tanks can be seriously threatened by a fire nearby, particularly in those cases where negligence or regulatory gaps allow a very close exposure of the vessels to flames coming from nearby fuels. In recent WUI fire events (e.g. Benitatxell, Spain, 2016; Madeira, Portugal, 2016; Calabassas, California, 2016, 2018) these type of LPG infrastructures were dangerously involved 
in the WUI fire emergency. Tanks were subjected to intense fire exposures, provoking loss of containment due to safety relief valves opening, giving rise to subsequent jet fires. Although in none of these cases major events were observed, the magnitude of the consequences in case of explosion could have been devastating, given the high population and asset density that usually characterize WUI areas.

Current Spanish set-up and maintenance standards [21] were not developed with real WUI fire exposure scenarios in mind and, as such, safety distances from the LPG supply units to vulnerable elements have been revealed insufficient. According to Spanish provisions, a scenario of a $5-\mathrm{m}^{3}$ LPG tank closely (i.e. $3 \mathrm{~m}$ ) surrounded by a fence made of a highly flammable ornamental hedgerow (e.g. Cupresus arizonica) is permitted to be set and obviously entails an inherent risk. There is a clear overlooked hazard associated with domestic LPG storage tanks that has to be addressed by redefining set-up conditions and safety distances according to the physical processes involved in the exposure of tanks to residential fires.

\section{Conclusions}

The presence and expansion of wildland-urban interface areas into existing and upcoming fireprone zones in Europe is becoming a paramount concern for the protection of human life, homes, infrastructures and businesses against forest fires. In the years to come, self-protected communities will be the first priority over fire suppression, entailing more and best prepared WUI scenarios grounded on solid and sound guidelines and legislation. As of today, the European Union is way behind this requirement, so do the Member States which poorly have developed such regulations. Although the Spanish administration has some legislations in place, these are conspicuously deficient when addressing the factors and processes which take place in the destruction of communities and human life. Additionally, the lack of risk culture and community awareness is one of the main causes of defective policy implementation in some Spanish municipalities. Based on a detailed review of codes, guidelines, plans and recommendations on WUI fire prevention and management in Spain, we have pointed out critical needs that have to be addressed by scientific research. The complexity of the WUI fire problem requires multidisciplinary expertise, including among others, architects, engineers (covering landscape, civil and fire disciplines), forest and social scientists. In this paper we highlight several research efforts covering specific fire science and engineering topics to be explored and fostered so to provide solid foundations to the guidelines and regulations. Some of them have received little attention in the literature about European WUI fires and some others have been almost unexplored. Among these, some of the most relevant are: the design and dimension of firebreaks surrounding communities following a physics-based approach and with focus on fuel reduction; 
the improvement of firefighting scenario by optimizing the design of road networks and water systems; the study of the ignitability and combustibility of residential fuels (either natural managed fuels or non-natural fuels, with special focus on green hedges) and fuels involved in industrial interfaces; the research and development of building codes and study of materials. Outcomes from these research activities should lead to appropriately drive and inform the policy making processes on WUI fire prevention and management in Spain and, by extension, in Southern European countries under a similar situation. 
Table 1. Summary of provisions at national and regional level in terms of fuel management and defence infrastructures. NRA: No further requirements/recommendations available. Autonomous regions not included in the table (Andalucía, Aragón, Cantabria, C. León, C. La Mancha, Euskadi, Illes Balears, La Rioja, Murcia and Nafarroa) do not have further developed standards.

\begin{tabular}{|c|c|c|c|}
\hline $\begin{array}{l}\text { National / } \\
\text { regional level }\end{array}$ & Fuel-reduced fringes & Access roads & Water network \\
\hline Spain & $\begin{array}{l}\text { The fuel-reduced strip must have a } 30-\mathrm{m} \text { (or } 8 \text { times } \\
\text { the vegetation height) width including a } 5-\mathrm{m} \text { clean } \\
\text { road around WUI communities. It must have no dry } \\
\text { vegetation and a cleared arboreal strata. }\end{array}$ & $\begin{array}{l}\text { WUI communities must have two different access } \\
\text { roads or, alternatively, one access road ending at a } \\
\text { circular ( } 12.5 \mathrm{~m} \text { radius) cul-de-sac. } \\
\text { Roads have to be } 3 \mathrm{~m} \text { (one-lane road) or } 5 \mathrm{~m} \text { (two- } \\
\text { lane road) wide, with a } 5 \text { - } \mathrm{m} \text { minimum internal } \\
\text { turning radius and a } 5 \mathrm{~m} \text { height free of obstacles. } \\
\text { Slopes on roads have to be lower than } 12 \% \text { (being } \\
20 \% \text { exceptionally accepted). } \\
\text { There must be a change of direction zone of } 200 \mathrm{~m}^{2} \\
\text { and } 8 \text { meters long every } \mathrm{km} \text {. }\end{array}$ & $\begin{array}{l}\text { WUI communities must have a hydrant network } \\
\text { around their perimeter with } 100 \mathrm{~mm} \text { diameter } \\
\text { pipelines ensuring } 1 \text { bar of pressure at the outlet, and } \\
17 \mathrm{l} / \mathrm{s} \text { of minimum flow rate. }\end{array}$ \\
\hline Canarias & $\begin{array}{l}\text { Recommendation on arboreal strata treatment: } 3 \mathrm{~m} \\
\text { of distance between treetops. }\end{array}$ & NRA & NRA \\
\hline Catalunya & $\begin{array}{l}\text { Recommendation on fuel treatments: } 3 \mathrm{~m} \text { of } \\
\text { distance between treetops in flat terrain, } 6 \mathrm{~m} \text { in } \\
\text { moderate slope and } 9 \mathrm{~m} \text { in high slope. Shrubs must } \\
\text { be hardly present. } \\
\text { Fuels-reduced fringes must have a width of } 50 \mathrm{~m} \text { in } \\
\text { high risk areas. } \\
\text { Internal plots in WUI communities have to be also } \\
\text { fuel-reduced as external fringes. }\end{array}$ & $\begin{array}{l}\text { Recommendations on fuel treatments in access } \\
\text { roads: trees must be pruned up to } 3.5 \mathrm{~m} \text {; ditches } \\
\text { have to be clear of dry vegetation. }\end{array}$ & $\begin{array}{l}2 \text { hydrants working for } 2 \text { hours providing a flow rate } \\
\text { of } 1000 \mathrm{I} / \mathrm{min} \text { at } 1 \text { bar. }\end{array}$ \\
\hline $\begin{array}{l}\text { Comunidad de } \\
\text { Madrid }\end{array}$ & $\begin{array}{l}\text { Internal plots in WUI communities have to be also } \\
\text { fuel-reduced as external fringes. }\end{array}$ & $\begin{array}{l}\text { Requirements on fuel treatments in access roads: } \\
\text { ditches and roads have to be clear of any type of } \\
\text { vegetation. }\end{array}$ & NRA \\
\hline
\end{tabular}




\begin{tabular}{|c|c|c|c|}
\hline Extremadura & $\begin{array}{l}\text { Fuel-reduced fringes must have a width of } 50 \mathrm{~m} \text { in } \\
\text { high risk areas. }\end{array}$ & $\begin{array}{l}\text { Complementary requirements regarding road } \\
\text { characteristics for crossroads and turning areas: } \\
\text { access roads must have complementary turning ways } \\
\text { ( } 8 \mathrm{~m} \text { long and } 4 \mathrm{~m} \text { wide) perpendicular to their } \\
\text { direction }\end{array}$ & $\begin{array}{l}\text { Complementary requirements: the hydrant network } \\
\text { must provide } 1000 \mathrm{l} / \mathrm{min} \text { at } 1 \text { bar for } 2 \text { hydrants } \\
\text { (undefined simultaneity period requirement) }\end{array}$ \\
\hline Galicia & $\begin{array}{l}\text { Fuel-reduced strip width enlarged up to } 50 \mathrm{~m} \text { in all } \\
\text { cases and doubled }(100 \mathrm{~m}) \text { for strong winds. }\end{array}$ & NRA & NRA \\
\hline $\begin{array}{l}\text { Principado de } \\
\text { Asturias }\end{array}$ & $\begin{array}{l}\text { Fuel-reduced fringes lay out must form a two ring } \\
\text { structure. Internal ring of } 50-\mathrm{m} \text { width, cleared of } \\
\text { shrubs and with } 20 \% \text { of canopy cover. External ring } \\
\text { of } 75-\mathrm{m} \text { width, with no vertical and horizontal } \\
\text { continuity, } 15 \% \text { of shrub cover and } 40 \% \text { of canopy } \\
\text { tree cover. }\end{array}$ & NRA & NRA \\
\hline $\begin{array}{l}\text { Comunitat } \\
\text { Valenciana }\end{array}$ & $\begin{array}{l}\text { Fringe width must be dimensioned by a rule-based } \\
\text { methodology according to general meteorological } \\
\text { conditions, slope, and fuel models. Fuel-reduced } \\
\text { fringe width enlarged up to } 50 \mathrm{~m} \text { for slopes higher } \\
\text { than } 30 \% \text {. } \\
\text { Fuel treatment requirement in internal plots: shrub } \\
\text { clearance ( } 10 \% \text { cover), canopy tree clearance }(40 \% \\
\text { cover), pruning height at } 2 / 3 \text { of tree height. }\end{array}$ & $\begin{array}{l}\text { Complementary requirements: access roads must } \\
\text { have a } 10 \text {-m wide strip at each side, without shrubs, } \\
\text { with a reduced canopy cover }(20 \%) \text { and pruned trees } \\
\text { at } 2 / 3 \text { of their height. }\end{array}$ & $\begin{array}{l}\text { Complementary requirements: the hydrant network } \\
\text { must provide } 1000 \mathrm{l} / \mathrm{min} \text { at } 1 \text { bar for } 2 \text { hydrants } \\
\text { during } 2 \text { hours. }\end{array}$ \\
\hline
\end{tabular}




\section{References}

1. EEA (European Environment Agency) (2017) Climate change, impacts and vulnerability in Europe 2016. An indicator-based report. EEA Report No1/2017. doi: 10.2800/53480. https://www.eea.europa.eu/publications/climate-change-impacts-and-vulnerability-2016.

Accessed 7 January 2019

2. Hagelin H, Cluzel M (2016) Applying FARSITE and Prometheus on the Västmanland Fire, Sweden (2014): fire growth simulation as a measure against forest fire spread: a model suitability study. Student thesis series INES nr 375. In Student thesis series INES NGEK01 20161. http://lup.lub.lu.se/student-papers/record/8881384. Accessed 7 January 2019

3. Wigtil G, Hammer RB, Kline JD, Mockrin MH, Stewart SI, Roper D, Radeloff VC (2016) Places where wildfire potential and social vulnerability coincide in the coterminous United States. Int J Wildland Fire 25(8):896-908

4. Johnston LM, Flannigan MD (2018) Mapping Canadian wildland fire interface areas. Int J Wildland Fire. https://doi.org/10.1071/WF16221

5. San-Miguel-Ayanz J, Durrant T, Boca R, Libertà G, Branco A, de Rigo D, Ferrari D, Maianti P, Artes Vivancos T, Costa H, Lana F, Löffer P, Nuijten D, Leray T, Ahlgren AC (2018) Forest fires in Europe, Middle East and North Africa 2017. EUR 29318 EN. Publications Office of the European Union. doi: 10.2760/663443 (online). Accessed 7 January 2019

6. Ribeiro LM, Vendrell J, Arvieu P, Caballero D (2015) Deliverable D1.1 report on WUI fire prevention and emergency management in Europe: a state of the art and guidelines for improvement. Wildland-Urban Interface Forest Fire Risk Observatory and Interest Group in Europe WUIWATCH. https://www.dropbox.com/s/ef2hdvcf0ydivmw/WUIWATCH D1.1.pdf?dl=0. Accessed 7 January 2019

7. Modugno S, Balster H, Cole B, Borrelli P (2016) Mapping regional patterns of large forest fires in wildland-urban interface areas in Europe. $J$ Environ Manag http://dx.doi.org/10.1016/i.jenvman.2016.02.013

8. MAPAMA (Ministerio de Agricultura y Pesca, Alimentación y Medio Ambiente) (2017) Los incendios forestales en España. 1 enero - 31 diciembre 2017 - Avance Informativo. Gobierno de España. $\quad$ https://www.mapa.gob.es/es/desarrollo-rural/estadisticas/iiff 2017 def tcm30446071.pdf. Accessed 7 January 2019

9. MAPAMA (Ministerio de Agricultura y Pesca, Alimentación y Medio Ambiente) (2018) Los incendios forestales en España. Decenio 2001-2010. Gobierno de España. https://www.mapa.gob.es/es/desarrollo-rural/estadisticas/incendiosforestales20012010finalmod1 tcm30-132603.pdf Accessed 26 May 2019

10. Caballero D, Beltrán I, Velasco A (2007) Forest fires and wildland-urban interface in Spain: Types and risk distribution. 4th International Wildland Fire Conference, 14-17 May 2007, Sevilla, Spain

http://gfmc.online/doc/cd/SESIONES TEMATICAS/ST5/Caballero et al_SPAIN Tecnoma.p df. Accessed 7 January 2019

11. Ribeiro, L.M., Rodrigues, A., Lucas, D., Viegas, D.X. (2018). The large fire of Pedrógao Grande (Portugal) and its impact on structures. In: Viegas DX (ed) Advances in Forest Fire Research 2018. Chapter 4 - Fire at the Wildland Urban Interface, pp 852-858. https://doi.org/10.14195/978-989-26-16-506 94 
12. Armero G, Molina F, Gómez P (2009) El aprovechamiento de la biomasa forestal primaria (BFP) para fines energéticos como oportunidad para los propietarios forestales privados. In: Sociedad Española de Ciencias Forestales (ed) $5^{\circ}$ Congreso Forestal Español, Ávila, 21-25 September 2009, Spain

13. Castellnou M (2018) Wildfires in Catalunya. Forum on Catalan Wildfire Research. 6 November 2018, Barcelona, Catalonia. https://lessonsonfire.eu/en/document/wildfires-catalunya

14. Galiana L (2012) Las interfaces urbano-forestales: un nuevo territorio de riesgo en España. Boletín de la Asociación de Geógrafos Españoles 58:205-226. ISSN 0212-9426. https://www.ucm.es/data/cont/docs/530-2013-10-15-09-GALIANA.pdf. Accessed 7 January $\underline{2019}$

15. Greenpeace (2018) Protege el bosque, protege tu casa. Informe ampliado, pp 140. https://es.greenpeace.org/es/wp-content/uploads/sites/3/2018/06/Protege-tu-casa-protege-elbosque.pdf. Accessed 7 January 2019

16. Boletín Oficial del Estado (2003) Ley 43/2003, de 21 de noviembre, de Montes. https://www.boe.es/eli/es/1/2003/11/21/43/con. Accessed 7 January 2019

17. Boletín Oficial del Estado (2013) Real Decreto 893/2013, de 15 de noviembre, por el que se aprueba la Directriz Básica de planificación de protección civil de emergencia por incendios forestales. https://www.boe.es/eli/es/rd/2013/11/15/893. Accessed 7 January 2019

18. Boletín Oficial del Estado (2015) Ley 17/2015, de 9 de julio, del Sistema Nacional de Protección Civil. https://www.boe.es/eli/es/1/2015/07/09/17/con. Accessed 7 January 2019

19. Boletín Oficial del Estado (2006) Real Decreto 314/2006, de 17 de marzo, por el que se aprueba el Código Técnico de la Edificación. https://www.boe.es/eli/es/rd/2006/03/17/314/con. Accessed 7 January 2019

20. Boletín Oficial del Estado (2004) Real Decreto 2267/2004, de 3 de diciembre, por el que se aprueba el Reglamento de seguridad contra incendios en los establecimientos industriales. https://www.boe.es/eli/es/rd/2004/12/03/2267/con. Accessed 7 January 2019

21. Asociación Española de Normalización y Certificación (2008) Installations for the storage of GLP in fixed vessels for its use in installations. UNE 60250:2008. Madrid

22. Cohen JD (2004) Relating flame radiation to home ignition using modeling and experimental crown fires. Canadian J For Res 34(8):1616-1626

23. Cohen JD (2000) Preventing Disaster: Home Ignitability in the Wildland-Urban Interface. J For 98:15-21. https://www.fs.fed.us/rm/pubs_other/rmrs_2000_cohen_j002.pdf. Accessed 7 January 2019

24. Council of Standards Australia (2009) Australian Standard ${ }^{\circledR}$ Construction of buildings in bushfire-prone areas. AS 3959-2009. Standards Australia. 110 pp.

25. Eisenberg NA, Lynch CJ, Breeding RJ (1975) Vulnerability model: a simulation system for assessing damage resulting from marine spills, USCG, AD-A015 245, NTIS Report no. CG-D$136-75$

26. Mell WE, Manzello SL, Maranghides DB, Butry D, Rehm RG (2010) The wildland-urban interface fire problem - current approaches and research needs. Int J Wildland Fire 19:238-251 
27. Ronchi E, Rein G, Gwynne SMV, Intini P, Wadhwani R (2017) Framework for an integrated simulation system for Wildland-Urban Interface fire evacuation. 119-134. Paper presented at Fire Safety 2017, Cantabria, Spain. http://portal.research.lu.se/portal/files/34159613/Framework_for_an_integrated_simulation_syst em_for_Wildland_Urban_Interface fire evacuation_final.pdf. Accessed 7 January 2019

28. Fu G, Kapelan Z, Kasprzyk JR, Reed P (2013) Optimal design of water distribution systems using many-objective visual analytics. J Water Resour Plan Manag 139(6):624-633

29. Dalmau F, Caballero D, Quinto F (2018) Carcaixent fire impact against a self-protected WUI zone.: lessons learned. In: Viegas DX (ed) Advances in Forest Fire Research 2018. Chapter 4 Fire at the wildland-urban interface, pp 726-735. https://doi.org/10.14195/978-989-26-16-506 79

30. Ganteaume A, Jappiot M, Lampin C, Guijarro M, Hernando C (2013a) Flammability of some ornamental species in wildland-urban interfaces in southeastern France: laboratory assessment at particle level. Environ Manag 52:467-480

31. Ganteaume A, Jappiot M, Lampin C (2013b) Assessing the flammability of surface fuels beneath ornamental vegetation in wildland-urban interfaces in Provence (southeastern France). Int J Wildland Fire 22:333-342

32. Ganteaume A, Romero B (2018) Terpene-containing species vs terpeneless species: what best drives flammability of ornamental species used in WUI? In: Viegas DX (ed) Advances in Forest Fire Research 2018. Chapter 4 - Fire at the wildland-urban interface, pp 846-851. https://doi.org/10.14195/978-989-26-16-506_93

33. Pastor E., Caballero D., Cozzani V., Heymes F., Ribeiro L.M., Vilalta O., Sjöström J. (2019) WUIVIEW - Wildland-urban interface virtual essays workbench: summary of the action. CERTEC-UPC Technical Report 1902. 6 pp. Available at:

https://www.wuiview.org/download/Summary $\% 20$ of $\% 20$ the $\% 20$ action_def.pdf

34. Manzello, SL, Suzuki, S, Nii, D (2017) Full-Scale Experimental Investigation to Quantify Building Component Ignition Vulnerability from Mulch Beds Attacked by Firebrand Showers, Fire Technol 53: 535-551.

35. Manzello, SL and Suzuki, S (2017) Experimental Investigation of Wood Decking Assemblies Exposed to Firebrand Showers, Fire Saf J 92: 122-131.

36. Leonard JE, Blanchi R, Bowditch PA (2018) Bushfire impact from a house perspective. A background support document for ongoing work in the Bushfire CRC, Bushfire CRC, Australia

37. Krausmann E, Baranzini D (2012) Natech risk reduction in the European Union. J Risk Res 15(8): 1027-1047.

38. Pastor E, Caballero D, Martín J, Planas E (2018) Risk analysis of LPG tanks at the wildlandurban interface: are regulated safety distances large enough? In: Viegas DX (ed) Advances in Forest Fire Research 2018. Chapter 7 - Short contributions, pp 1351-1353. https://doi.org/10.14195/978-989-26-16-506 176 